\title{
A Passive Solar Air-House Conditioning System Integrated in Tunisian households
}

\author{
Majdi Hazami*, Sami Kooli and Nabiha Naili
}

Laboratoire de Procédés Thermiques, Centre de recherches et des Technologies de l'Energie; Technopôle de Borj. Cedria Hammam-Lif BP 95

\begin{abstract}
In Tunisia, the buildings' space heating sector represents a major part of the total energy consumption budget. These issues have been increasingly prominent concerns since the energy crisis. Hence, interests have been growing to adopt renewable energies as viable sources of energy that offer a wide range of exceptional benefits with an important degree of promise, especially in the buildings sector. However, the management of renewable energy sources for space air heating/cooling is usually not economically feasible compared with the traditional carriers. In this chapter, we present a passive energy system, called air-conditioning cupboard which exploits renewable energies (hot water supplied from solar collector $\left[40-50^{\circ} \mathrm{C}\right]$ and cold groundwater $\left(19^{\circ} \mathrm{C}\right)$ ) as thermal sources, is conceived and tested in our laboratory (Laboratory of Thermal Procedure, LPT Tunisia). To evaluate the air-conditioning cupboard efficiency indoor experiments were carried out under varied Tunisian environmental conditions for several days. Results show that the airheating system has good thermal effectiveness $(80 \%)$. It permits to the maintenance of the temperature inside the experimented room at the range of $\left[24-27^{\circ} \mathrm{C}\right]$ during the cold months and $\left[20-23^{\circ} \mathrm{C}\right]$ during hot months. A theoretical model is employed for the sizing of the air-conditioning cupboard to obtain the required temperature values. This model allows also the determination of the air-cupboard conditioning thermal performances.
\end{abstract}

Keywords: Solar energy, Solar storage collector, Air-conditioning cupboard.

\section{INTRODUCTION}

The demand in Tunisia for energy in hot months (For cooling) and cold months (For heating) is increasing very fast. Indeed, in Tunisia, six months (From May to October) are the hot months $\left(32^{\circ} \mathrm{C}\right)$ of the year, and June, July, and August are the months of the harsh condition of heat $\left(40^{\circ} \mathrm{C}\right)$. The other six months (From November to April) are characterized by fairly humid and cold climates $\left[15-20^{\circ} \mathrm{C}\right]$. It is, hence, necessary to build comfortable conditions indoor buildings. Figure 1 shows the typical daily temperature changes during one year obtained from the meteorological station installed in our laboratory (Laboratory of Thermal Procedure, LPT, Tunisia).

Unfortunately, in Tunisia, the investment costs for the commercialized heating systems, ventilating and air conditioning systems, which consume sizeable quantities of primary energy, are still relatively high. The most amounts, approximately $50 \%$, of the total electric energy and fossil fuel which becomes scarce and expensive is spent on heating/cooling purposes in the buildings sector.

In an environmental context, wide efforts have been undertaken to alleviate global warming of earth caused

*Address correspondence to this author at the Laboratoire de Procédés Thermiques, Centre de recherches et des Technologies de l'Energie; Technopôle de Borj. Cedria Hammam-Lif BP 95; Tel: 0021697062734;

E-mail: hazamdi321@yahoo.fr by the emission of carbon dioxide in the atmosphere generated by intensive burning of fossil fuels is leading to environmental degradation in heavily populated areas [1-3]. There seems to exist, therefore, a pressing need to study alternative means of air conditioning and to identify and implement strategies to save energy while maintaining a comfortable environment in buildings. Accordingly, interest has been strongly growing to adopt solar energy and cold groundwater as viable sources of energy that offers a wide range of exceptional benefits for present and future apply with an important degree of promise. These resources represent a marketable massive energy potential, which greatly exceeds fossil fuel resources [4-9]. Indeed, Tunisia is blessed with abundant sunshine thus making it appropriate to select solar energy for different domestic purposes. The maximum intensity of solar energy at sea level is approximately $2.59 \mathrm{MJ} / \mathrm{h} . \mathrm{m}^{2}$ and the amount of solar energy that falls on one square meter ranges from about 2.8-9.4 GJ/year depending on the location. The ambient weather conditions are also suitable for introducing solar energy technologies.

Deep groundwater used for buildings air-cooling during the hot months of the year involves using naturally cold water as a heat sink in a heat exchange system, eliminating the need for conventional airconditioning. The expected economic and environmental benefits were realized, but barriers to large-scale adoption of the technology were apparent. 
This technology requires that a client with a large cooling need is near a deep, cold body of water.

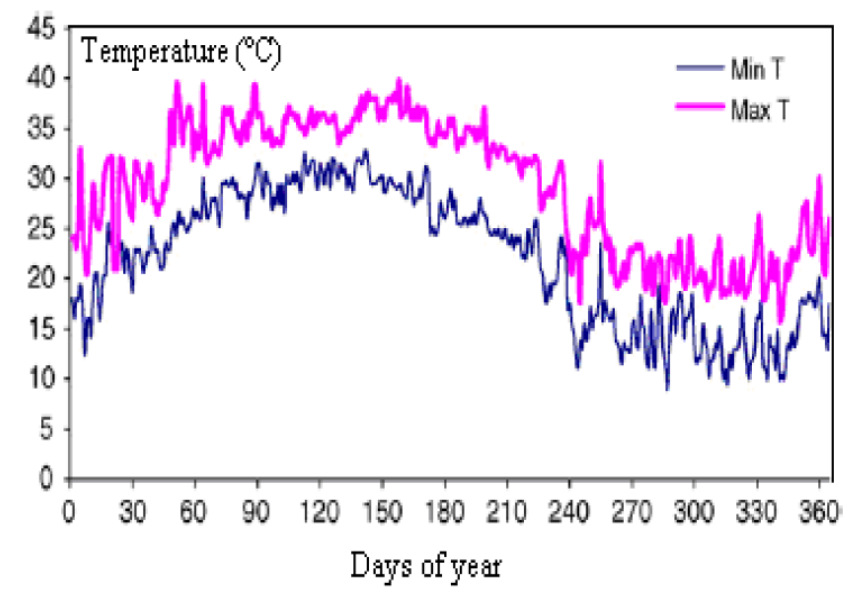

Figure 1: Temperature changes during one year.

As per the environmental point of view, the use of solar energy and cold groundwater respectively for buildings air-heating and air-cooling can play an important role to safe the environment and to improve our quality of life, while reducing fossil energy consumption. However, the management of renewable energy sources is usually not economically feasible compared with traditional carriers. From another hand, the problems of renewable energy are associated with distribution, access, and security of supply. To overcome the present economic, regulatory, and institutional barriers it is necessary to develop an efficient system capable to exploit renewable energy sources with satisfactory costs.

The originality in this work is due to the fact that it deals with an innovative system that can be included in management programs aiming to reduce at least the cost of the air-conditioning system by the application of renewable energies sources $[10,11]$. Thus, a trial prototype for a passive air-conditioning system is presented in this chapter. It consists of an airconditioning cupboard designed and manufactured in our laboratory (Figure 2). The passive air-conditioning system is leading to exploit hot water $\left[40-50^{\circ} \mathrm{C}\right]$ supplied from a solar collector for air-heating during cold months and cold groundwater at a constant temperature $\left(19^{\circ} \mathrm{C}\right)$ for air-cooling. This system is expected to satisfy the demand for household heating and cooling with lower costs than standard airconditioning systems.

\section{EXPERIMENTAL INVESTIGATION}

A schematic diagram for the air-conditioning system consisting of an air-conditioning cupboard (2), a solar storage collector $(3)$, and two wells $(12,13)$ bored next to the laboratory is shown in Figure 2.
(1) Tested room

(2) Air-conditioning cupboard

(3) Solar storage collector

(4) Flowmetre

(5) Pump

(6) Sliding valve

(7) Sliding valve

(8) Sliding valve

(9) Sliding valve

(10) Pump

(11) Flowmetre
(12) Well

(13) Well

(14) Data acquisition chart

(15) PC

(16) Ambient tempertaure

(17) Collector inlet water temperature

(18) Collector outlet water temperature

(19) Cupboard inlet temperature

(20) Cupboard outlet temperature

(21) Pyranometre

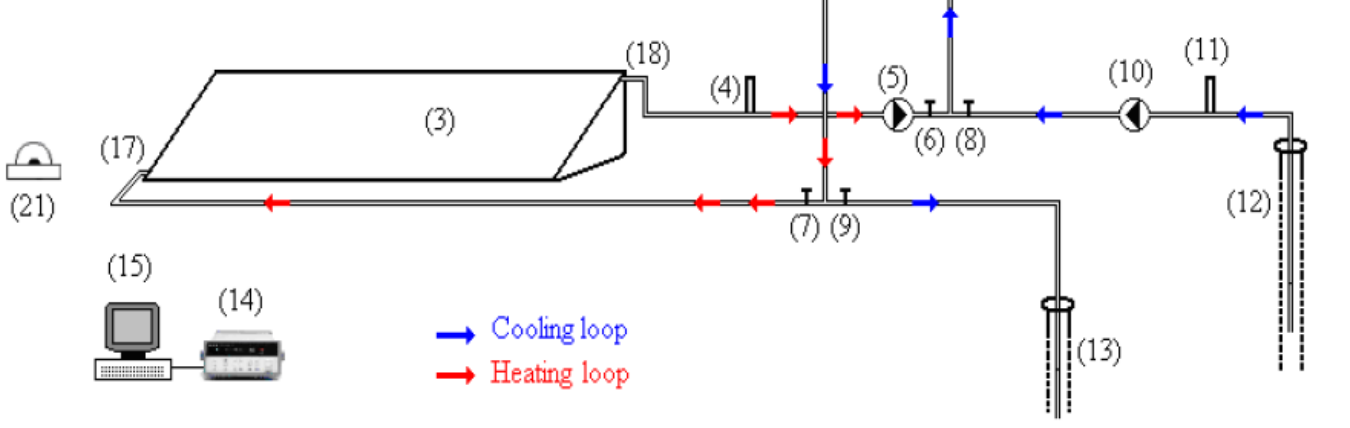

Figure 2: Diagram of the air-conditioning system. 


\subsection{Air-Conditioning Cupboard Description}

The air-conditioning cupboard, made in Plexiglas (2 $\mathrm{m} \times 1.5 \mathrm{~m} \times 0.1 \mathrm{~m}$ ), is equipped with two traps placed in the top and the bottom (Figure 3, and 4) [12]. On its two lateral sides, a network of low-cost polypropylene capillary heat exchangers is fixed. An airflow circulates naturally between the two traps permit the exchange of the thermal energy through the air-conditioning cupboard placed inside an experimented room (the width is $3 \mathrm{~m}$, the length is $4 \mathrm{~m}$, and the height is $3 \mathrm{~m}$ ). The experimented room has one window and one door. Room walls consist of masonry of a thickness of $0.2 \mathrm{~m}$, thermal conductivity of $1.6 \mathrm{~W} \cdot \mathrm{m}^{-1} \cdot \mathrm{K}^{-1}$, the density of 990 $\mathrm{kg} / \mathrm{m}^{3}$, the specific heat of $1260 \mathrm{~J} \mathrm{~kg}^{-1} \mathrm{~K}^{-1}$, and coefficient of the surface radiation emission of 0.56 . In Table 1 is represented the room technical specifications.

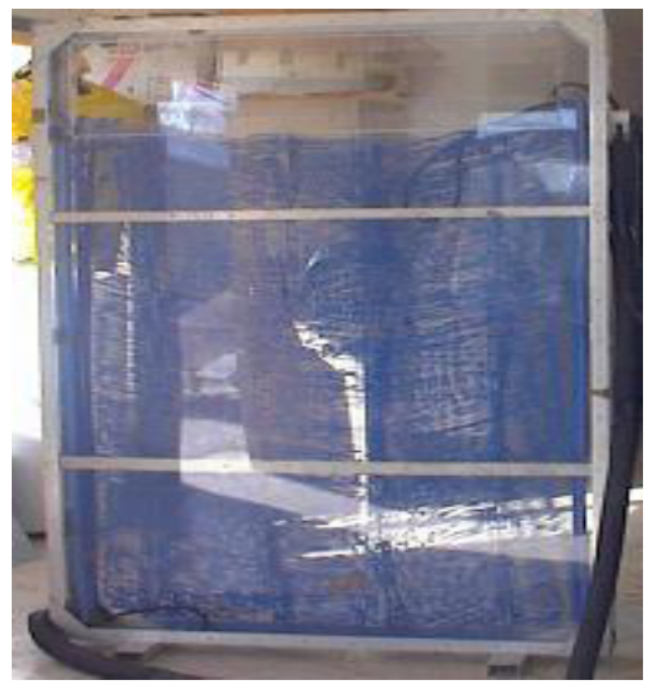

Figure 3: Photo of the air-conditioning cupboard.

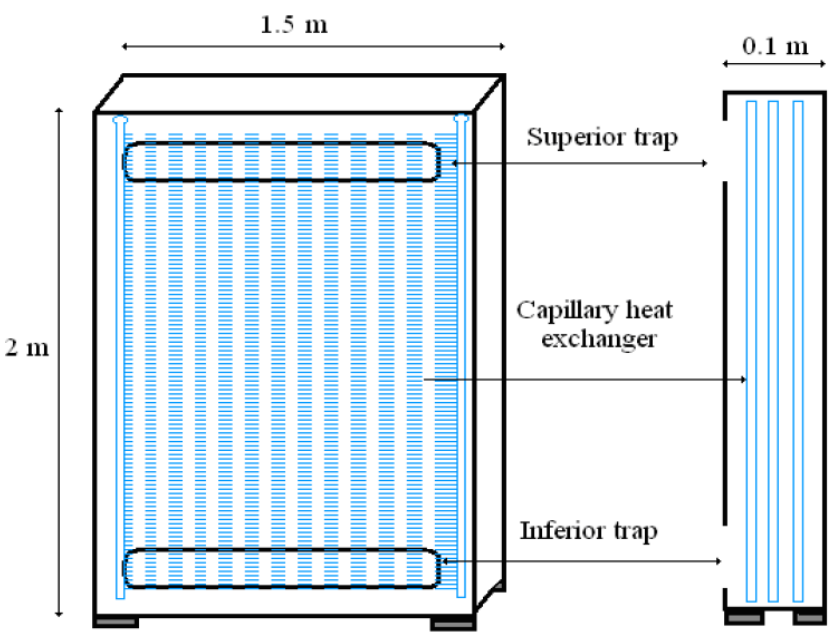

Figure 4: Descriptive diagram of the air-conditioning Cupboard.
Table 1: The Room Technical Specifications

\begin{tabular}{|c|l|}
\hline Parameter & \multicolumn{1}{|c|}{ Description } \\
\hline \hline Wall & $\begin{array}{l}\text { Bricks, thickness }=20 \mathrm{~cm}\left(\mathrm{k}=1.6 \mathrm{~W} \cdot \mathrm{m}^{-1} \cdot{ }^{\circ} \mathrm{C}^{-1} ;\right. \\
\left.\rho=990 \mathrm{~kg} \cdot \mathrm{m}^{-3} ; \text { solar heat absorption }=0.56\right)\end{array}$ \\
\hline Roof & $\begin{array}{l}\text { Concrete blocks, thickness }=36 \mathrm{~cm} \\
\left(\mathrm{k}=1.6 \mathrm{~W} \cdot \mathrm{m}^{-1} \cdot{ }^{\circ} \mathrm{C}^{-1} ; \text { solar heat absorption }=0.98\right)\end{array}$ \\
\hline Door & $4 \mathrm{~cm}$-thick woods \\
\hline Window & Iron frame, $1.5 \mathrm{~m} \times 1.5 \mathrm{~m}$ \\
\hline Glass & Reflex glass, $4 \mathrm{~mm}$ thick \\
\hline Built over area & $1800 \mathrm{~m}^{2}$ \\
\hline Lighting & Lighting heat load $=15 \mathrm{~W} \cdot \mathrm{m}^{-2}$ \\
\hline
\end{tabular}

\subsection{Solar Storage Collector Description}

A low-cost solar storage collector of a total aperture area of $5 \mathrm{~m}^{2}$, that does not need a storage tank, is conceived and realized in (Laboratory of Thermal Procedure, LPT, Tunisia) (3) [13]. The absorber matrix is in concrete painted black and having a $50 \mathrm{~mm}$ thickness. The concrete matrix performs the function of the storage tank. The thermal conductivity and specific heat of the concrete absorber are equal to $0.81 \mathrm{~W} . \mathrm{m}^{-}$ ${ }^{1} \cdot \mathrm{K}^{-1}$ and $880 \mathrm{~J} \cdot \mathrm{kg}^{-1} \cdot \mathrm{K}^{-1}$ respectively. A polypropylene capillary heat exchanger with an aperture area of $5 \mathrm{~m}^{2}$ is embedded inside the concrete absorber. The capillary heat exchanger permit to carry the heat transfer water inside the solar storage collector. A transparent double layers PVC cover with a thickness of $3 \mathrm{~mm}$ (transmission and emissivity coefficients are respectively, 81 and $94 \%$ ) was placed over the solar storage collector. An air space gap with a thickness of $20 \mathrm{~mm}$ is maintained between the cover and absorber (front-pass). A $30 \mathrm{~mm}$-thick polyurethane foam with thermal conductivity and specific heat respectively equal to $0.32 \mathrm{~W} \cdot \mathrm{m}^{-1} \cdot \mathrm{K}^{-1}$ and $2090 \mathrm{~J} \cdot \mathrm{kg}^{-1} \cdot \mathrm{K}^{-1}$ was placed on the back of the absorber plate and on the casing sides of the solar collector to minimize heat loses. In Figure $\mathbf{5}$ is represented some stages of the solar storage collector construction.

\subsection{Description of the Frigorific Source}

For the air cooling purpose, we have bored two wells next to the laboratory $(50 \mathrm{~m})$. The first well, bored at 20-m depth (12), supplies cold water at a constant temperature (about $19^{\circ} \mathrm{C}$ ). The groundwater extracted from this well is used as a frigorific source. The second well (13) was bored at 4-m depth is used to evacuate the water at the outlet of the air-conditioning cupboard (Figure 2). 

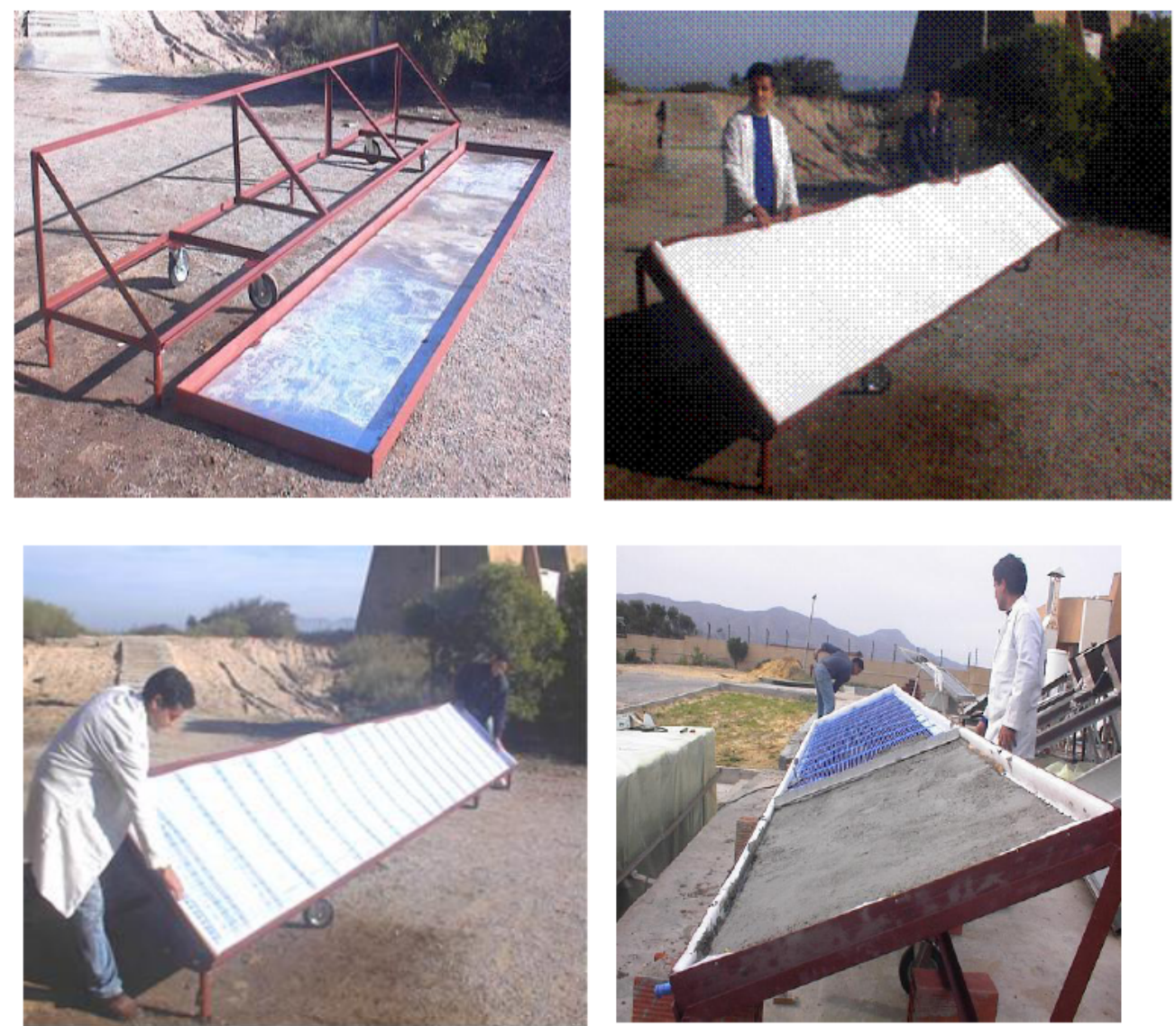

Figure 5: Different stages of the solar storage collector construction.

\subsection{The Air-Conditioning System's Operation}

Throughout the day a great part of the absorbed solar energy is stored inside the concrete matrix. When the solar radiation deceases the concrete matrix supplies the stored energy to the water within the heat exchanger embedded inside the absorber. This heat is used to provide house heating during the cold season (From November to February). When the air-room temperature decrease seriously, an automatic pump installed inside the heating loop (5) starts to operate and circulate the hot water supplied from the solar collector, at a temperature in the range of $\left[40-50^{\circ} \mathrm{C}\right]$, to the air-conditioning cupboard placed inside the tested room. The pump operates only when the temperature in the house is lower than the required values $(26 \pm 2$ ${ }^{\circ} \mathrm{C}$ ). The hot water supplied by the solar collector replenishes through the capillary heat exchanger placed inside the air-conditioning cupboard. This will continue until the air-room temperature reaches the required value.

It is useful to consider solar storage collectors as having three basic modes of operation, depending on the conditions that exist in the system at a particular time:

1. if solar energy is available and heat is not needed in the room, energy gain from the collector is added to storage inside the concrete matrix. To preserve the stored energy inside the concrete absorber during the night-time, the solar collector is covered by a double-layered panel of $4 \mathrm{~cm}$ thick of polystyrene,

2. if solar radiation is available and heat is needed in the room, energy gain from the collector is used to supply the room needs,

3. if solar radiation is not available (After 17:00 h, in winter seasons), the stored energy inside the concrete matrix is used to supply the room needs.

During hot months of the year (May to October) the air-conditioning cupboard is connected to the first well (12) by using the sliding valve (8). When the air-room temperature increase seriously the second automatic 
pump installed inside the cooling loop (10) circulates the cold water (at $19^{\circ} \mathrm{C}$ ) extracted from the first well to the air-conditioning cupboard.

The two pumps $(5,10)$ are programmed automatically to operate when the appropriate water temperature is reached. For the heating mode, only pump (5) is functioning, a control unit is integrated into the solar collector loop (pump 5). It follows the difference of collector inlet and outlet temperatures which is set to $+5^{\circ} \mathrm{C}$. If the difference between inlet and outlet temperatures of the collector is $\geq 5^{\circ} \mathrm{C}$, the control unit commands the pump "on", if it is $<5^{\circ} \mathrm{C}$ it commands the pump "off". For the cooling mode, the pump (5) is set "off" and only pump (10) is operating. For the cooling mode, the same control unit is using.

The return of the water from the air-conditioning cupboard is refuelled in the second well (13) by using a valve (9). This operation will continue until the air temperature in the tested room reaches the required value $\left(23^{\circ} \mathrm{C}\right)$.

Solar radiation is measured by a solar cell placed on a horizontal plane $1 \mathrm{~m}$ away from the solar storage collector and calibrated by an Eppley pyranometer (21) with an accuracy of $\pm 5 \%$. All temperatures are measured by type $\mathrm{T}$ and $\mathrm{K}$ thermocouples, including ambient temperature (16), inlet and outlet water temperatures $(19,20)$, and the temperature field in the room. The thermocouples were calibrated individually under different temperatures to obtain the calibration curves to be used for data processing with errors less than $0.1{ }^{\circ} \mathrm{C}$. The four measuring points in the tested room were set vertically apart with a distance of 500 $\mathrm{mm}$. The operation of the water pump was initially controlled using a timing device, so that water circulated between 09: 00 and 23: 00 . The rate of flow was controlled through a valve mounted at the outlet of the two pumps $(5,10)$ and the two flow metres $(4,11)$. The signals, then, are all automatically collected and recorded by a data acquisition system based on an HPMicro logger and PC $(14,15)$. All data were measured at $5 \mathrm{~s}$ intervals, from which 15-min averages were calculated and recorded.

\section{THERMAL ENERGY INVESTIGATION}

The numerical model is employed for the study of the air-conditioning system performances and to estimate the optimal air-conditioning cupboard sizing to reach the required indoor climate. This model allows to: (i) The evaluation of the useful heat delivered by the solar storage collector and the stored heat inside the concrete absorber matrix.

(ii) The overall heat exchange coefficient of the air conditioning cupboard.

(iii) The determination of the thermal efficiency of the air-conditioning system.

(iv) The determination of the heating/cooling needs.

(v) The estimation of the polypropylene capillary heat exchanger surface to integrate inside the air-conditioning cupboard to obtain an optimal function.

\subsection{Solar Storage Collector Characterization}

According to the INPUT/OUTPUT standard [14, 15], the useful heat delivered by the solar storage collector can be represented by the following empirical equation:

$Q_{u}(W)=\alpha_{1} G+\alpha_{2}\left(T_{a, a v}-T_{i, a v}\right)+\alpha_{3}$

The overnight heat loss coefficient $\left(U_{C}\right)$ of the hot water storage system is determined by measuring the temperature loss of the water during a $12 \mathrm{~h}$ nocturnal period [16]. The formula used is:

$U_{C}=\frac{M_{c} C_{p, c}}{A_{c} \Delta t} \ln \frac{T_{i}-T_{a, a v}}{T_{f}-T_{A b s, a v}}$

The daily solar collector's thermal efficiency $\bar{\eta}_{j}$ is given by the expression:

$\bar{\eta}_{j}=\eta_{o}-U_{c} \frac{T_{A b s, a v}-T_{a, a v}}{G_{a v}}-M_{c} C_{p, c}\left(T_{A b s, t_{2}}-T_{A b s, t_{1}}\right)$

Where; $t_{1}$ is the initial instant and $t_{2}$ is the final instant of the test period.

\subsection{Thermal Behavior of the Air-Conditioning System}

The role of the air-conditioning system is to maintain the tested room to an accurate temperature. To understand the thermal exchanges better inside the room, a numerical model has been developed. This model permits to evaluation of the energy needs of the room. We represent in the Figure 6, a schematic view of the different types of heats exchanged inside the room. The total heating/cooling load can be calculated 
by considering into account the effect of various parameters according to $[17,18]$ :

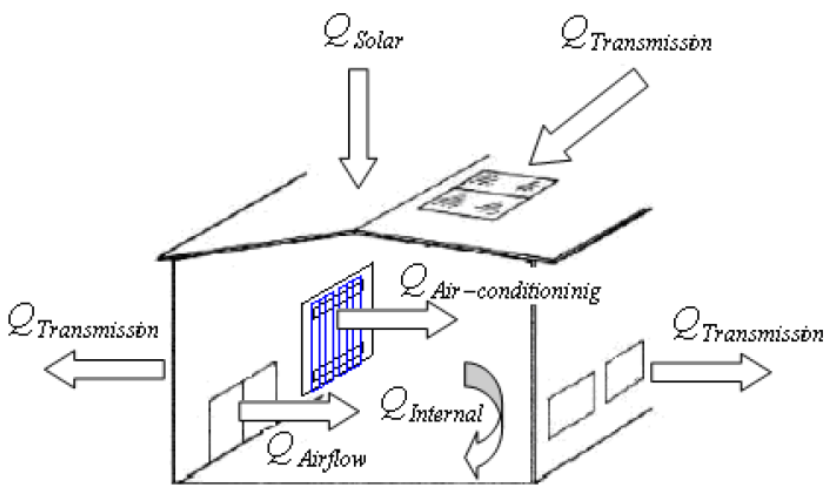

Figure 6: Schematic view different types of exchanges that occurs inside the tested room.

$Q_{P}=Q_{\text {Transmission }}+Q_{\text {Solar }}+Q_{\text {Internal }}+Q_{\text {Aifflow }}$

$Q_{p}$ represents the total heat transferred to the room air when water flowing through the polypropylene heat exchanger integrated inside the air-conditioning system. It was calculated from the temperature difference between the entrance and the exit of the capillary heat exchanger [19]:

$Q_{p}=\dot{m} C_{p}\left(T_{w, o}-T_{w, i}\right)$

Due to convection between the air surrounding and the water inside the polypropylene heat exchanger, the transferred heat can be also written as:

$Q_{p}=S U \frac{T_{w, o}-T_{w, i}}{\operatorname{Ln} \frac{T_{w, o}-T_{a}}{T_{w, i}-T_{a}}}$

The determination of the overall heat transfer coefficient, $U$, is obtained by using the electric analogy. The overall heat transfer coefficient, $U$, is given by $[20$, 21]:

$U=\frac{1}{\frac{1}{h_{\text {tube-air }}}+\frac{1}{h_{\text {tube }}}+\frac{1}{h_{\text {water }}}}$

Where: $h_{\text {tube-air }}, h_{\text {tube }}$ and $h_{\text {water }}$ were calculated by using relations ship given from appropriate tables $[22,23]$.

Eliminating $Q_{p}$ from (Eq.5) and (Eq.6) gives the exponential relation for the outlet temperature of the tube as a function of the ambient air and inlet temperature:

$T_{w, o}=T_{a}+\left(T_{w, i}-T_{a}\right) \exp \left(-\left(\frac{U S}{\dot{m} C_{p}}\right)\right)$
The indoor average temperature is given by the relation:

$T_{m}=\frac{1}{\exp (N U T)-1}\left[T_{w, i} \cdot \exp (N T U)-T_{w, o}\right]$

$N T U=\frac{U S}{\dot{M} C}$ represent the non-dimensional group is called the $\dot{\hat{N}} \mathrm{u}_{\mathrm{m}} \mathrm{mber}$ of Transfer Units.

The effectiveness of the air-conditioning cupboard is given by:

$E=\frac{T_{w, o}-T_{w, i}}{T_{a}-T_{w, i}}$

Using (7) the effectiveness becomes:

$E=1-\exp \left(-\left(\frac{U S}{\dot{m} C_{p}}\right)\right)$

Q Transmission represents the heat transfer from exterior walls, windows, doors and envelopes [24]:

$Q_{\text {Transmision }}=h_{i} \sum_{j=1}^{N_{w}} A_{w j}\left(T_{w i}-T_{a}\right)_{j}+A_{g j}\left(T_{g}-T_{a}\right)_{j}+A_{d j}\left(T_{d}-T_{a}\right)_{j}+h_{i R} \sum_{j=1}^{N R} A_{R j}\left(T_{R i}-T_{a}\right)_{j}$

Wall temperature must be calculated by mathematical modelling of the unsteady state heat transfer in the wall. It depends on radiation intensity, variations of external air temperature, and accumulation of heat inside the wall. The rate of heat absorption due to radiation on black bodies can be calculated by:

$Q_{\text {Rad }}=\alpha(G+D)$

$Q$ solar represents the heat due to sun radiation transmitted from windows. Thermal heat due to this phenomenon is calculated by using:

$Q_{\text {Solar }}=\tau_{G} G+\tau_{D} D$

$Q_{\text {Internal }}$ represents internal heat generated by the lighting system, persons in the building and home appliances can be calculated by using [25]:

$Q_{\text {Internal }}=Q_{\text {Lihting }}+Q_{\text {Persons }}+Q_{\text {Appliances }}$

The heat generated by lighting system can be calculated by using:

$Q_{\text {Lighting }}=P . F$

The heat generated by persons and appliances can be found from appropriate tables. 
$Q_{\text {Airflow }}$ is the heat due to airflow into the building (sensible and latent heat). Heat load due to outside airflow infiltration can be calculated by [26]:

$$
Q_{\text {Airflow }}=Q_{s}+Q_{L}
$$

Where:

$$
Q_{s}=\dot{V} \rho c_{p, a}\left(T_{a, 0}-T_{a, i}\right)=\dot{m}_{a} c_{p, a}\left(T_{a, 0}-T_{a, i}\right)
$$

(Sensible heat by entering air)

$Q_{L}=\dot{V} \rho\left(W_{i}-W_{0}\right) \lambda \quad$ (Latent heat by entering air)

The optimal value of the exchange surface necessary to maintain the indoor climate to the required conditions is given by the relation:

$$
S=\frac{\dot{m} C p}{U} \operatorname{Ln}\left[\frac{T_{w, i}-T_{a}}{T_{w, o}-T_{a}}\right]
$$

\section{RESULTS AND DISCUSSIONS}

\subsection{Solar Storage Collector Characterisation}

The solar storage collector constitutes the basic element for the air-heating loop. Therefore, outdoor experiments were carried out under winter weather conditions according to the Input-Output test method. The solar collector's efficiency for a selected winter day of December is shown in Figure 7. It can be seen that the efficiency starts to increase after dawn until it reaches its maximum value at noon, and then decreases again. The efficiency changed between 22 and $40 \%$.

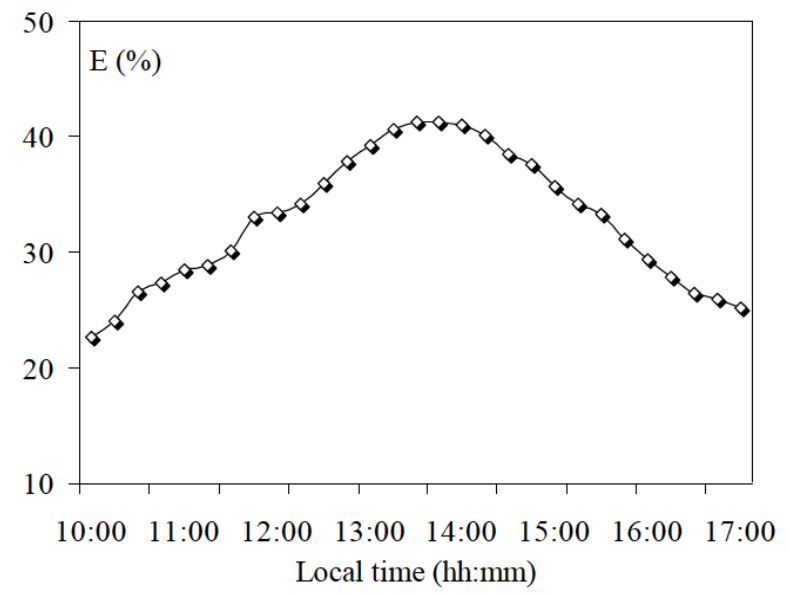

Figure 7: The variation of the solar storage collector efficiencies versus daytime.

The solar storage collector enjoys a daily efficiency $\left(\bar{\eta}_{j}\right)$ of $30 \%$ achieved at an average solar radiation level of $620 \mathrm{~W} . \mathrm{m}^{-2}$ and an ambient temperature of 20
${ }^{\circ} \mathrm{C}$. To appraise the solar storage collector heat loss coefficient, $U_{c}$, we have covered the solar storage collector with a $30 \mathrm{~mm}$-thick polyurethane foam while the circulation of water inside the heat exchanger is stopped. Then we followed the concrete absorber temperature decrease for about $24 \mathrm{~h}$. The overnight heat loss coefficient, $U_{c}$, is determined by equation 2 . It is assumed to be equal to $14 \mathrm{~W}$. ${ }^{\circ} \mathrm{C}^{-1}$. The solar radiation and the solar storage outlet water temperature increases are represented in Figure 8 (a, b). As expected, the outlet water temperature of the solar storage collector depends on solar radiation. During a typical sunny day of December, the outlet water temperature increases to a maximum value of 50 ${ }^{\circ} \mathrm{C}$ at $12: 30 \mathrm{pm}$ in the noon and remains almost constant for $3 \mathrm{~h}$ before it starts to decrease later in the afternoon.

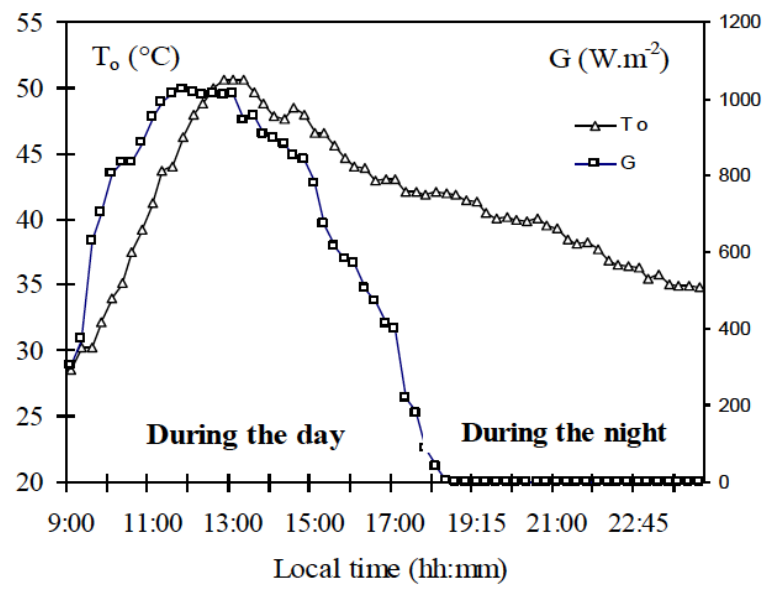

(a)

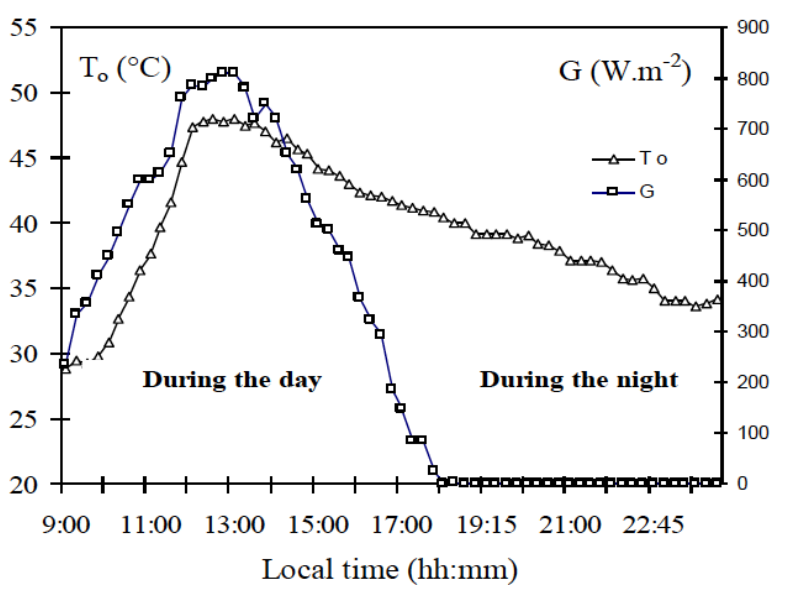

Figure 8: Outlet water temperature increase versus day times for mass flow rates and equal to $0.0416 \mathrm{~kg} . \mathrm{s}^{-1}$ for: (a) Sunny day of December $\left(20^{\circ} \mathrm{C}\right)$, (b) Cloudy day of December $\left(16^{\circ} \mathrm{C}\right)$.

During a typical winter cloudy day of December, characterized by a harshly solar radiation oscillation, we established that the outlet water temperature 
increases to a maximum value of $43^{\circ} \mathrm{C}$ at $12: 30 \mathrm{pm}$ in the noon and remains almost constant during 3-2 $\mathrm{h}$ before it starts to decrease later in the afternoon. We noted also that the temperature of the water at the solar collector outlet was not affected by solar radiation oscillation. The absorbed solar heat stored inside the concrete absorber is delivered to the capillary heat exchanger whilst the insulation starts to decrease (during the night) or swing ruthlessly (in winter days). This stored energy is used for the air-room heating during the cold season until at night. A variation of stored energy for different times during a typical winter day of December is presented in Figure 9. A maximum peak of stored energy, $3.5 \mathrm{~kW}$, is obtained at $13: 00 \mathrm{~h}$ and remains almost constant for $3 \mathrm{~h}$ then the stored energy decrease. To improve the stored thermal energy conservation we covered the solar collector surface with an insulation blanket before the hardly decreasing of solar radiation (after 17:00 h).

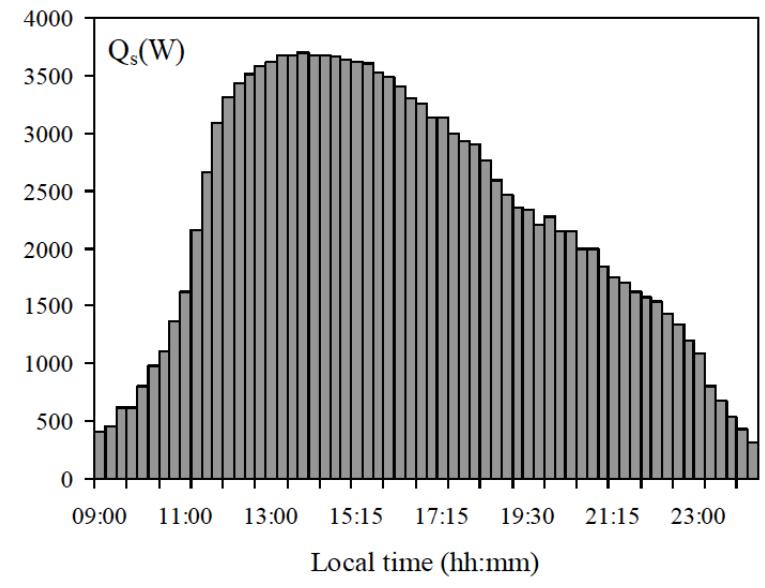

Figure 9: Stored energy within concrete variation versus time of day.

Nightly, the solar storage collector supplies about $400 \mathrm{~L}$ of hot water at a temperature of $45^{\circ} \mathrm{C}$ (above the human body temperature, $37^{\circ} \mathrm{C}$ ) until during winter. This quantity of heated water is circulated through a tubing system to the air-conditioning cupboard. Compared to the conventional solar collector, the concrete solar collector, that does not need a storage tank, presents satisfactory performances, and a low cost compared with a conventional solar collector (Table 2).

\subsection{Thermal Behavior of the Air-Conditioning Cupboard}

\subsubsection{The Air-Conditioning System Sizing}

The model allows calculating the optimal exchange surface of the capillary heat exchanger to place inside the air-conditioning system to reach the required air- room temperature. The estimation of the heat exchanger surface to place inside the air-conditioning system should take into account many parameters; (i) the heat exchanger performances (overall heat exchange coefficient, efficiency, and the optimal function parameters (heat exchanger length and water masse flow), (ii) the air-conditioning cupboard inlet water temperature (For heating and cooling load), (iii) the room climatic needs and (iv) the difference between indoor and outdoor temperature.

Table 2: Comparison between a Conventional Solar Collector and Solar Storage Collector

\begin{tabular}{|c|c|c|}
\hline & $\begin{array}{c}\text { Conventional Solar } \\
\text { Collector }\end{array}$ & $\begin{array}{c}\text { Solar Storage } \\
\text { Collector }\end{array}$ \\
\hline \hline Thermal efficiency & $38 \%$ & $30 \%$ \\
\hline System cost & $800 \$$ & $250 \$$ \\
\hline 1 kWh selling price & $0.05 \$$ & $0.02 \$$ \\
\hline Payback time & 8 years & 3 years \\
\hline
\end{tabular}

An analytical method is developed for the accurate calculation of the overall heat transfer coefficient and the thermal efficiency of the air-conditioning system. It consists of measuring the amount of temperatures of the inlet and the outlet of the heat exchanger and the air-room average temperatures. Experiments were carried out, varying the flow rate, the heat exchanger length (The width is fixed to $1 \mathrm{~m}$ ), and the inlet temperature. Results show that the maximal value of the overall heat exchange coefficient $\left(28 \mathrm{~W} \cdot \mathrm{m}^{-2} .{ }^{\circ} \mathrm{C}^{-1}\right)$ is obtained for a network of heat exchangers with $4 \mathrm{~m}$ length crossed by water at a masse flow equal to 200 I. $\mathrm{h}^{-1}$ (Figure 10).

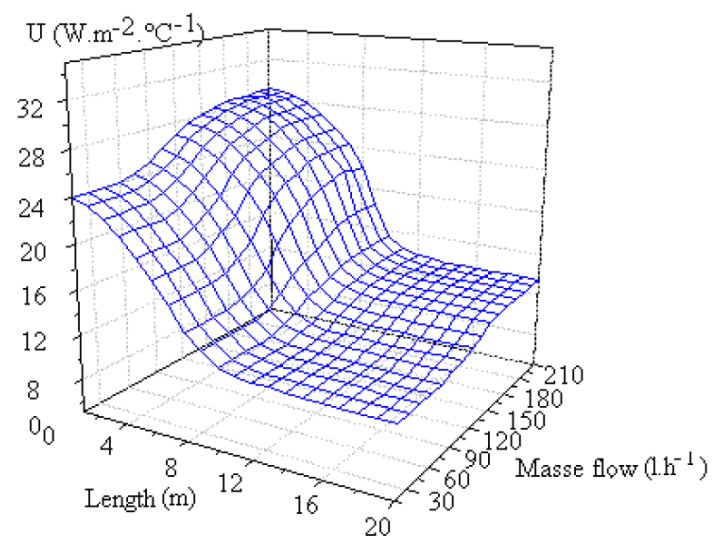

Figure 10: Numerical variation of the overall heat exchange coefficient according to the length and masse flow rates and a temperature equal to $\left[20^{\circ} \mathrm{C}-70^{\circ} \mathrm{C}\right]$.

The numerical and experimental efficiency profiles, for three networks of capillary heat exchangers with a 
fixed width $(1 \mathrm{~m})$ and different lengths $(3,4$, and $5 \mathrm{~m})$ and different masse flow rates are plotted in Figure 11. We noted that the net energy efficiency increase with masse flow rates and heat exchanger lengths. The efficiency reaches the higher value of $80 \%$ achieved for a heat exchanger length and masse flow rates respectively equals $4 \mathrm{~m}$ and $200 \mathrm{~L} . \mathrm{h}^{-1}$. We established that using a network of heat exchangers with $1 \mathrm{~m}$ width and a length superior to the optimal value of $4 \mathrm{~m}$ dose does not increase the capillary heat exchanger efficiency. We established also that for this optimal length $(4 \mathrm{~m})$ corresponds an optimal value of masse flow rate equal to $200 \mathrm{~L} . \mathrm{h}^{-1}$. It is obvious from Figure 11 that using a masse flow and a length lower than 200 L. $\mathrm{h}^{-1}$ and $4 \mathrm{~m}$ decreases seriously the air-conditioning system efficiency.

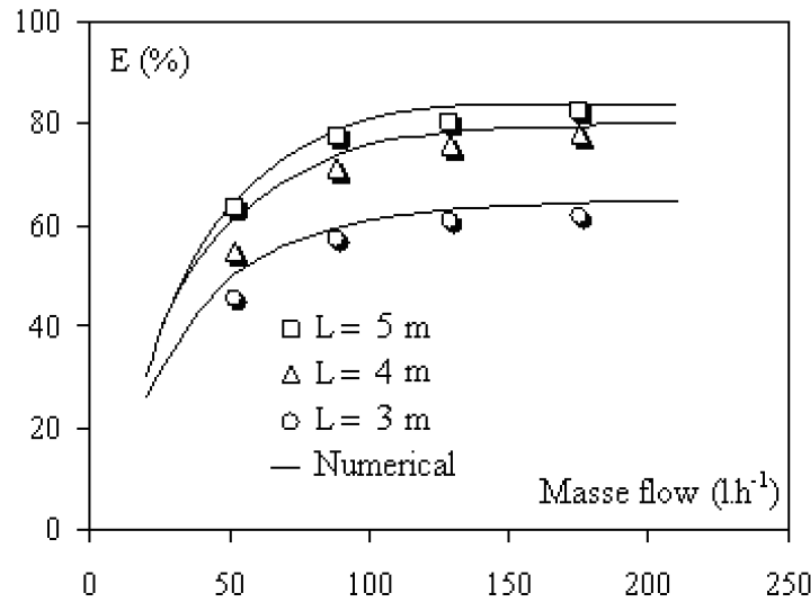

Figure 11: The variation of the solar storage collector efficiencies for different heat exchanger length and versus masse flow rates.

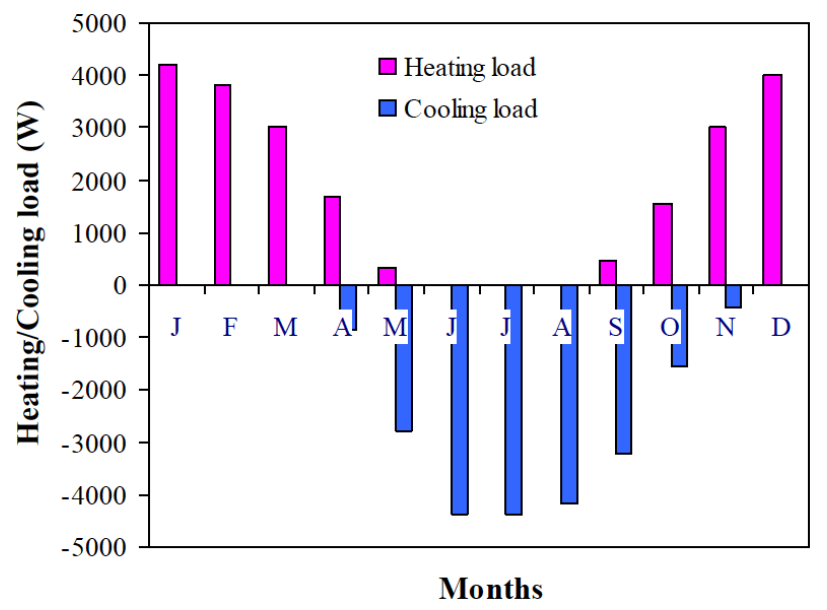

Figure 12: Annual heating and cooling needs.

The sizing of the air-conditioning system depends also on the difference between indoor and outdoor temperature and the tested room annual heating/cooling load needs. The numerical model described in this chapter $(\S 3.2)$ permits the estimation of the tested room energy needs to maintain the required indoor climate. Numerical results are shown in Figure 12 (heating need is shown as positive and cooling need is shown as negative). It is seen that for heating and cooling cases the maximal needs are 4.2 and $4.6 \mathrm{~kW}$, respectively.

\section{For the heating load}

To maintain the temperature of the tested room to the value of $26{ }^{\circ} \mathrm{C}$ it is necessary to place inside the air-conditioning system $9 \mathrm{~m}^{2}$ (Almost 2 networks of heat exchanger with the size; $1 \mathrm{~m} \times 4 \mathrm{~m}$ ) of the capillary heat exchanger crossed by hot water with a constant masse flow and temperature respectively equal to 200 L.h ${ }^{-1}$ and $\left[40-50^{\circ} \mathrm{C}\right]$. In Figure 13 , is represented the calculated variation of the thermal heating load, as well as the thermal heating, needs to reach the required temperature value within the tested room. Numerical results show that the air-heating loop provides a maximal value of thermal energy of about $3.5 \mathrm{~kW}$ to increase the air room temperature by about $\left[7-10^{\circ} \mathrm{C}\right]$. It is also seen that the heat load provided by the solar storage collector represents about $83 \%$ of the annual thermal heat needed to maintain the air-room temperature at about $26 \pm 3^{\circ} \mathrm{C}$.

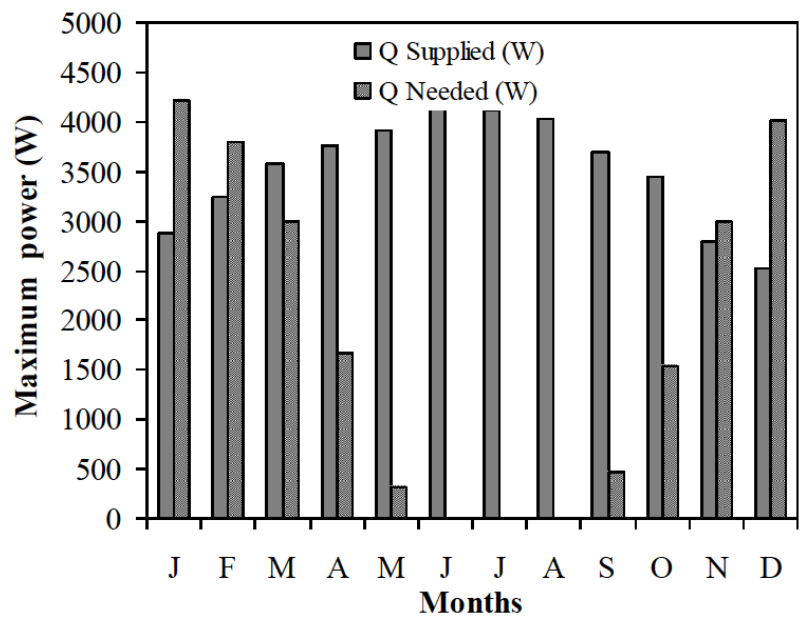

Figure 13: Maximum power in excess estimated and contribution heating necessary to maintain the air-room temperature, $26{ }^{\circ} \mathrm{C}$.

\section{For the cooling load}

The heat exchanger surface to place within the airconditioning system is assumed to be equal to $11 \mathrm{~m}^{2}$ (Almost 3 networks of heat exchanger with the size; $1 \mathrm{~m}$ $x 4 \mathrm{~m})$ crossed by cold groundwater $\left(19^{\circ} \mathrm{C}\right)$ with a 
masse flow of about $2001 . \mathrm{h}^{-1}$. In Figure 14, is represented the calculated variation of the thermal cooling load as well as the variation the thermal energy needs which should be evacuated to maintain the required temperature in the tested room at the value of $23^{\circ} \mathrm{C}$. The results show that it is necessary to provide refrigerated energy of the order of $4.3 \mathrm{~kW}$ to maintain the room temperature at the required value. The heat load that should be extracted by air-conditioning system represents $95 \%$ of the annual thermal heat needed to maintain the air-room temperature at the required value.

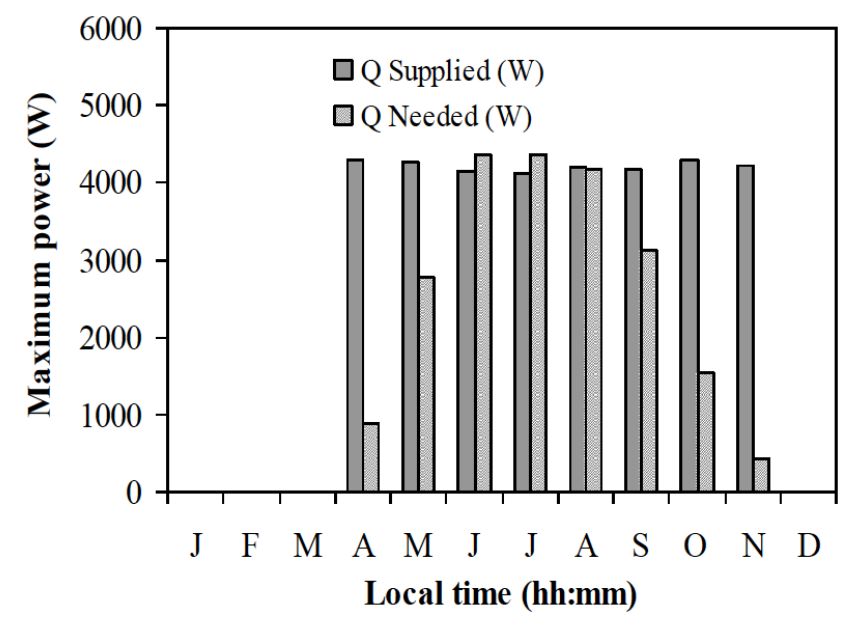

Figure 14: Maximum power in excess estimated and contribution cooling necessary to maintain the air-room temperature, $26^{\circ} \mathrm{C}$.

Table 3 summarises the needed and loaded energy rates according to the required indoor temperature. It is seen that both the heating and cooling loops cover easily the energy needs especially for cooling purposes. This is explained by the fact that the frigorific source (Groundwater) represents a constant temperature all over the year $\left(19{ }^{\circ} \mathrm{C}\right)$ while the hot water supplied by the solar collector presents a variable temperature $\left[40-47^{\circ} \mathrm{C}\right]$. This is because the water at the solar storage collector outlet depends on solar insolation.

\subsubsection{Performances of the Air Conditioning System}

The air-heating loop and the air-cooling loop were respectively investigated during cold months of the year (November to April) and all through hot months of the year (May to October). Inside the air-conditioning system was fixed $12 \mathrm{~m}^{2}$ (3 networks of polypropylene heat exchanger with the size; $1 \mathrm{~m} \times 4 \mathrm{~m}$ ) of a capillary heat exchanger. The hot/cold water masse flow was fixed within the air heating/cooling loops at the value $200 \mathrm{I} . \mathrm{h}^{-1}$. Many thermocouples (Types T and K) were set in different places inside the tested room to indicate the evolution of the indoor climate for different applications and the overall experimental investigation.

The hot water supplied by the solar storage collector is pumped to the capillary heat exchanger positioned within the air-conditioning cupboard. Figure 16 represents the air temperature field in the tested room. The results show that the use of hot water [30 $45^{\circ} \mathrm{C}$ ] provided by the solar storage collector, permits to increase of the air room temperature about 7 to 10 ${ }^{\circ} \mathrm{C}$. We noted that the indoor temperature reaches it is the maximum value after 40 minutes of air-conditioning function. Figure 15 shows also that the more elevated temperature reach in the local $\left(30^{\circ} \mathrm{C}\right)$ is gotten at $2 \mathrm{~m}$ height. In fact; inside the tested room gets settled a temperature gradient of about $2.5^{\circ} \mathrm{C} / \mathrm{m}$.

In an independent test, we kept the air-heating system operating continuously for about $14 \mathrm{~h}$. The result of the experience is drawn in Figure 16 which shows the inside and outside temperatures variation for a selected winter day (December. 15 ${ }^{\text {th }}, 2006$ ). The figure shows that the indoor temperature is lower in the early morning and then starts to increase until it reaches its maximum value $\left(30^{\circ} \mathrm{C}\right)$ in the afternoon before decreasing again. This is typical of Tunisian climate during winter because a great period of the day is sunny.

Table 3: Summary of the Loads/Needs

\begin{tabular}{|c|c|c|c|}
\hline & Maximum (kW) & Annual Consuption (MWh) & (\%) Consumption \\
\hline \hline Heating load & 3.5 & 70.4 & \\
\hline Heating need & 4.2 & 86.4 & 83 \\
\hline Cooling load & 4.1 & 89.2 & \\
\hline Cooling need & 4.3 & 93.5 & \\
\hline
\end{tabular}




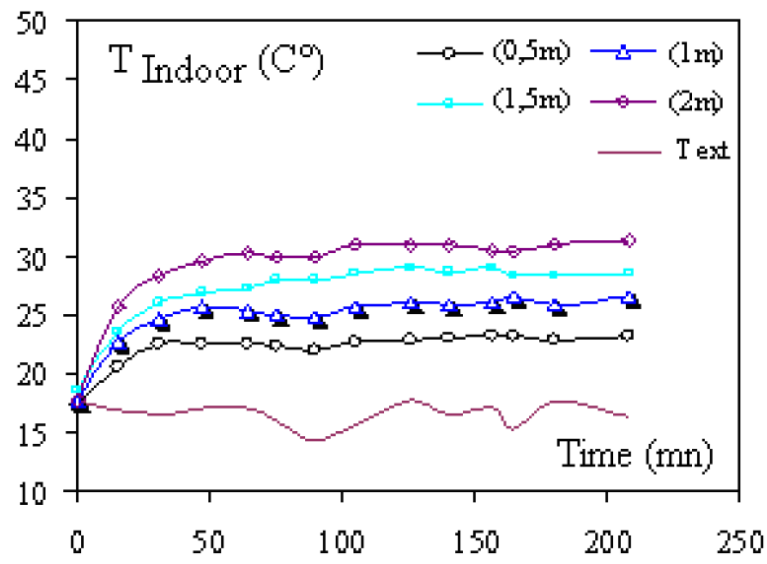

Figure 15: The air temperature vertical profile in the tested room.

The air heating loop demonstrates a satisfactory ability to meet a moderate indoor climate compared to the outdoor climate. The gap between the indoor and the outdoor temperature reaches $4-10{ }^{\circ} \mathrm{C}$, especially during the night. The average solar storage energy inside the concrete absorber is $21.74 \mathrm{~kW}$ in the whole operation (14 h), and it attains $25.04 \mathrm{~kW}$ during the working hours from 9:00 to 17:00, which is sufficient to keep the indoor thermal environment at the average temperature of $26 \pm 2{ }^{\circ} \mathrm{C}$.

Figure 16 shows also that the inside temperature was kept around the desired value $\left(26^{\circ} \mathrm{C}\right)$ for a great period of the day and night (From 10:00 to 21:00). Concerning the whole heating period, the air-heating loop was capable of meeting the heating requirement in 60 days. However, during a cloudy day, the fluctuation of the air temperature in the experimented room becomes more serious due to the daily insolation oscillation. In this case the stored solar energy is also affected by the critical insolation decreasing.

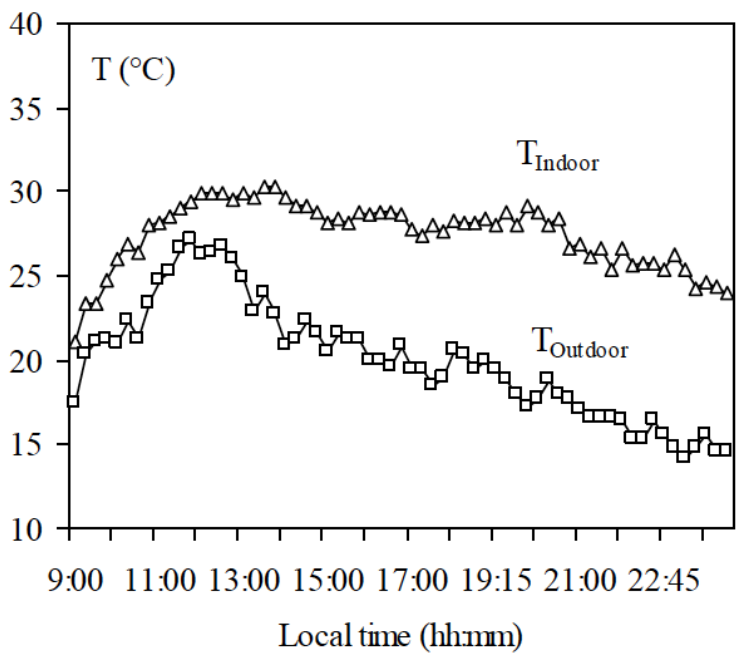

Figure 16: Variations of indoor and outdoor temperature.
The cooling loop is usually used in summer when the average outdoor temperature and relative humidity are respectively about $37.3^{\circ} \mathrm{C}$ and $50 \%$. In the Figure 17 are represented the indoor temperature field. Results show that the use of the groundwater well (19 ${ }^{\circ} \mathrm{C}$ ), for the air-conditioning cupboard, permits to decrease of air room temperature to about $8{ }^{\circ} \mathrm{C}$. On the other hand, the air room temperature vertical profile shows that the weakest temperature reached in the local $\left(23^{\circ} \mathrm{C}\right)$ is gotten to a height of $0.5 \mathrm{~m}$ from soil. Same as the heating case we found inside the tested room the same temperature gradient (About $2{ }^{\circ} \mathrm{C} / \mathrm{m}$ ). Until in cooling case, the indoor temperatures reach their maximum values after 40 minutes of airconditioning function.

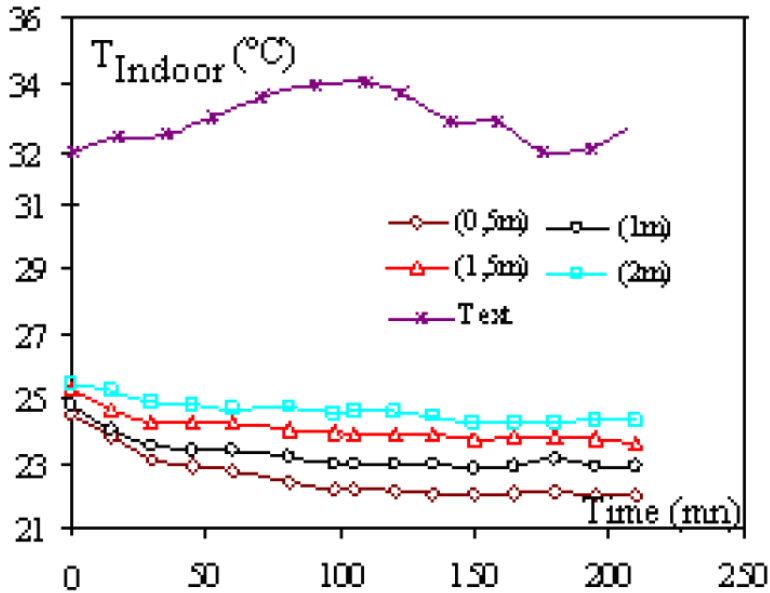

Figure 17: The air temperature field in the tested room.

In Figure 18, is represented the numerical and experimental variation of the air room temperature as well as the daily outside air temperature evolution. The

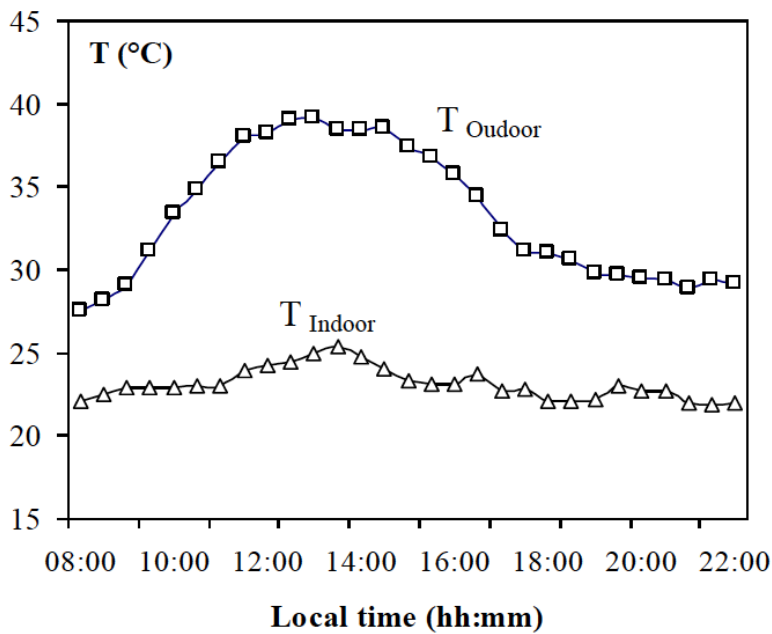

Figure 18: Variations of all-day room temperatures (heated and non heated). 
results show that the air cooling loop permits the decreasing of the room air temperature of about [4$13^{\circ} \mathrm{C}$. We also note that although the outdoor temperature increases seriously, mainly during the included time between 11:00 $\mathrm{h}$ and 16:00 $\mathrm{h}$, the indoor temperature doesn't vary; it is about $23^{\circ} \mathrm{C}$.

\section{CONCLUSION}

Based on the results obtained from the performance analysis of the passive air-conditioning system in a demonstration room, the following results are obtained:

(i) The air-conditioning system enjoys a maximum overall heat exchange coefficient $\left(28 \mathrm{~W} . \mathrm{m}^{-2} .{ }^{\circ} \mathrm{C}^{-1}\right)$ and total efficiency of about $80 \%$ achieved for an optimal heat exchanger length and masse flow rates respectively equals to $4 \mathrm{~m}$ and 200 L.h $\mathrm{h}^{-1}$.

(ii) The numerical model allows the estimation of the tested room heating/cooling energy needs. For heating and cooling loads the maximal needs are estimated to be respectively equal to 4.2 and $4.6 \mathrm{~kW}$.

(iii) It is also seen that to maintain the temperature of the tested room to the value of $26^{\circ} \mathrm{C}$ (during heating loop function) it is necessary to place inside the airconditioning cupboard $9 \mathrm{~m}^{2}$ of the capillary heat exchanger crossed by hot water with a constant masse flow and temperature range respectively equal to 200 L. $\mathrm{h}^{-1}$ and $\left[40-50^{\circ} \mathrm{C}\right]$. The air-heating loop provides a maximal value of thermal energy of about $3.5 \mathrm{~kW}$ to increase the air room temperature by about $\left[7-10^{\circ} \mathrm{C}\right]$.

(iv) For the cooling load the heat exchanger surface to place within the air-conditioning cupboard is assumed to be equal to $11 \mathrm{~m}^{2}$ crossed by cold groundwater $\left(19^{\circ} \mathrm{C}\right)$ with a masse flow of about 200 L. $\mathrm{h}^{-1}$. The thermal cooling load provides $4.3 \mathrm{~kW}$ of frigorific energy to maintain the room temperature at the value of $23^{\circ} \mathrm{C}$.

(v) For both heating/cooling loops the heat load that should be provided/extracted by air-conditioning system covers easily the energy needs. They represent between 83 and $95 \%$ of the annual thermal heat needed to maintain the air-room temperature at the required value during the whole heating/cooling period. The air heating/cooling loops demonstrate a satisfactory ability to meet a moderate indoor climate compared to the outdoor climate by maintaining during the night a gap between the indoor and the outdoor temperature (about $4-13^{\circ} \mathrm{C}$ ).

\section{ACKNOWLEDGEMENTS}

The authors gratefully acknowledge the support of this work through Laboratoire de procédés Thermiques, LPT, Centre de Recherches et des Technologies de l'Energie, CRTEn, de Borj Cedria, Tunisia.

\section{NOMENCLATURE}

$A_{c} \quad$ Surface area of the collector $\left(\mathrm{m}^{2}\right)$

$A_{d} \quad$ Surface area of doors $\left(\mathrm{m}^{2}\right)$

$A_{g} \quad$ Surface area of glasses of windows $\left(\mathrm{m}^{2}\right)$

$A_{w} \quad$ Surface area of walls $\left(\mathrm{m}^{2}\right)$

$D \quad$ Diffusive intensity of radiation

$F \quad$ Lighting coefficient ( $F=1.2$ for florescent lamps and 1 for others)

$C_{p, c}$ Specific heat of air at constant pressure $(\mathrm{kJ} / \mathrm{kg} \mathrm{K})$

$C_{p} \quad$ Specific heat of water at constant pressure $(\mathrm{kJ} / \mathrm{kg} \mathrm{K})$

$\mathrm{C}_{\mathrm{p}, \mathrm{a}} \quad$ Specific heat of air at constant pressure

G Solar radiation $\left(\mathrm{W} / \mathrm{m}^{2}\right)$

$h_{i} \quad$ Heat transfer coefficient $\left(\mathrm{W} / \mathrm{m}^{2} .{ }^{\circ} \mathrm{C}\right)$

$h_{i R}$ Heat transfer coefficient of the air under the roof $\left(\mathrm{W} / \mathrm{m}^{2} \cdot{ }^{\circ} \mathrm{C}\right)$

P Power consumption for lighting system

$\dot{m}$ Water mass flow rate $(\mathrm{kg} / \mathrm{s})$

$\dot{m}_{a} \quad$ Air mass flow rate $(\mathrm{kg} / \mathrm{s})$

$M_{c} \quad$ Concrete mass $(\mathrm{kg})$

$\Delta t \quad$ Time period (s)

$T$ Temperature $\left({ }^{\circ} \mathrm{C}\right)$

$\dot{V} \quad$ Volumetric flow rate of air

$U_{c}$ heat loss coefficient $\left(\mathrm{W} / \mathrm{m}^{2} .{ }^{\circ} \mathrm{C}\right)$

\section{Greek letters}

a absorption coefficient

$\alpha_{1} \quad$ Input-output test coefficient $\left(\mathrm{m}^{2}\right)$

$\alpha_{2}, \alpha_{3}$ Input-output test coefficient (MJ/K) 
$\lambda \quad$ Latent heat if vaporisation

$\rho \quad$ Density of air

TG Transmission coefficient of glass for direct solar radiation

TD Transmission coefficient of glass for diffuse solar radiation

$\eta_{0} \quad$ Optical yield (dimensionless)

$\overline{\eta_{j}} \quad$ Thermal efficiency (dimensionless)

\section{Subscripts}

a Ambient air temperature $\left({ }^{\circ} \mathrm{C}\right)$,

Abs Absorber

av Average

c Concrete

e Environment

f Final

g glass

i Inlet

o Outlet

$\mathrm{Ri} \quad$ Internal roof surface

w Water

wi Interior surface of the wall

\section{REFERENCES}

[1] Niu JL, Kooi Jvd, Ree Hvd. Energy saving possibilities with cooled-ceiling systems. Energy and Buildings. 1995; 23: 14758.

https://doi.org/10.1016/0378-7788(95)00937-X

[2] Niu JL, Kooi Jvd. Indoor climate in rooms with cool ceiling systems. Building and Environment 1994; 29: 283-90. https://doi.org/10.1016/0360-1323(94)90024-8

[3] Mertz G. Chilled ceilings and ventilating systems-thermal comfort and energy saving. Air Infiltration Review 1992; 13: 7-10.

[4] Jager F. (1981). Solar energy applications in houses. Luxembourg, Commission of the European Communities.

[5] ASHRAE. (1977). Handbook of fundamentals. New York: American Society of Heating and Air Conditioning Engineers

[6] Yellott JI. (1971). Solar heating and cooling of houses. In: Sayigh AM, editor. Solar energy engineering. Academic Press, New York, (chapter 17).
Kiruma K. (1983). Utilization of solar energy, the Japanese experience in solar energy application in the tropics. New York: Reidel Publishing Company.

[8] McVeigh J. (1983). Sun power, an introduction to the application of solar energy. Oxford (UK): Pergamon Press.

[9] Lof G, Karaki. (1983). System performance for the supply of solar heat. Mechanical Engineering, Des 33 \pm 47 .

[10] Lundsager P. Integration of renewable energy into local and regional power supply. World Energy Council 1996; 117-22. https://doi.org/10.1016/0960-1481(96)88829-X

[11] Archibald J. Building integrated solar thermal roofing systems history, current status, and future promise. Proceedings of the solar 99 conference. Maine: American Solar Energy Society (ASES). 1999; 95-100.

Hazami M, Kooli S, Lazaar M, Farhat A, Belghith A. Heat transfer characteristics of a capillary heat exchanger based air conditioning cupboard. Desalination 2004; 166: 435-442. https://doi.org/10.1016/i.desal.2004.06.098

[13] Hazami M, Kooli S, Lazaar M, Farhat A, Belghith A. Performance of a solar storage collector. Desalination 2005; 183: $167-172$

https://doi.org/10.1016/j.desal.2005.03.033

[14] R. Ranjit (1990). A primer on the Taguchi method. Dearborn, Ml: Society of Manufacturing Engineers

[15] Tsui K-L. An overview of Taguchi method and newly developed statistical methods for robust design. IIE Trans 1992; 24(5): 44-57. https://doi.org/10.1080/07408179208964244

[16] Bourges B, Rabl A, Leide B, Carvalho MJ. and Collares. Pereira M. Accuracy of the European solar water heater test procedure. Part 1: Measurement errors and parameter estimates. Part 2: Prediction of long-term performance. Solar Energy 1991; 47: 1-25. https://doi.org/10.1016/0038-092X(91)90058-5

[17] Hong T, Jiang Y. A new multizone model for the simulation of building thermal performance, Building and Environment 1997; 32(2): 123-128. https://doi.org/10.1016/S0360-1323(96)00045-5

[18] Hatamipour MS, Mahiyar H, Taheri M. Evaluation of exising cooling sustems for reducing cooling power consumption. Energy and Buildings 2007; 39: 105-112. https://doi.org/10.1016/i.enbuild.2006.05.007

[19] Hazami M. Etude expérimentale et numérique du phénomène de stockage et du déstockage de l'Energie thermique en utilisant un échangeur capillaire en polypropylène. Thesis 2008; $124-127$

[20] KS. Lee et JY. Yun. Investigation of heat transfer characteristics on various kinds of fin and tube heat exchangers with interrupted surfaces", Int. J. Heat and Mass transfer. 1999; Vol. 42.

https://doi.org/10.1016/S0017-9310(98)00310-X

[21] Claesson J. Correction of logarithmic mean temperature difference in a compact brazed plate evaporator assuming heat flux governed flow boiling heat transfer coefficient. International Journal of Refrigeration 2005; 28: 573-578. https://doi.org/10.1016/j.ijrefrig.2004.09.011

[22] Batasani A, Feibig M, Mitra NK. Numerical studies of a compact fin tube heatexchanger", Design and Operation of heat Exchangers, Springer-Verlag, Berlin. 1992; 154-163. https://doi.org/10.1007/978-3-642-84450-8 14

[23] Feibig $M$, Grosse-Gorgemann A, Chen Y, Mitra NK. Congugate heat transfer of finned tube part $\mathrm{A}$ : heart transfer behavior and occurrence of heat transfer reserval", Numerical Heat Transfer. Part A 1995; 28: 133-146 https://doi.org/10.1080/10407789508913737

[24] Sharian A, Shalabi B, Rousan A, Tashtoush B. Effects of the absorptance of external surfaces on heating and cooling loads of residential buildings in Jordan. Energy Conversion \& 
Management 1998; 39(3/4): 273-284. https://doi.org/10.1016/S0196-8904(96)00185-9

[25] Jiang $Y$. State space method for analysis of the thermal behavior of rooms and calculation of air-conditioning load, ASHARE Transactions 1981; 88: 122-132.
[26] Shaviv E, Yezioro A, Capelurto IG. Thermal mass and night ventilation as passive cooling design strategy. Renewable Energy 2001; 24: 445-452.

https://doi.org/10.1016/S0960-1481(01)00027-1

Received on 08-06-2021

Accepted on 23-08-2021

Published on 17-09-2021

DOI: $\underline{\text { https://doi.org/10.31875/2410-2199.2021.08.6 }}$

(C) 2021 Hazami et al:; Zeal Press.

This is an open access article licensed under the terms of the Creative Commons Attribution Non-Commercial License (http://creativecommons.org/licenses/by-nc/3.0/), which permits unrestricted, non-commercial use, distribution and reproduction in any medium, provided the work is properly cited. 